\title{
Dietary carbohydrates and protein of yeast modulate the early stages of innate immune response in tilapia (Oreochromis niloticus) primarily after LPS inoculation
}

\author{
Natalia $\mathrm{Ha}^{1}$ - André Fernando Nascimento Gonçalves ${ }^{1}$ • \\ Luana Camargo Sousa ${ }^{1} \cdot J_{\text {Jaqueline Dalbello Biller-Takahashi }}{ }^{1}$ • \\ Leonardo Susumu Takahashi ${ }^{1}$
}

Received: 3 December 2015/Accepted: 26 September 2016/Published online: 3 October 2016

(C) Springer International Publishing Switzerland 2016

\begin{abstract}
The administration of yeast-derived immunostimulants leads to improvement of the immune system and growth performance preventing the antibiotics misuses. The objective of this study was to evaluate the effects of dietary Actigen ${ }^{\circledR}[0,0.04,0.06$ and $0.08 \%$ of Actigen (ACT)], on the immunological and physiological responses and growth performance of tilapia after lipopolysaccharide (LPS) inoculation. The experiment was conducted in two trials. In the first trial, the ACT was offered for 30 and 60 days; in the second trial, the ACT was offered for 60 days, and then fish were challenged by intraperitoneal injection with LPS and sampled at 5 and 12 days after inoculation. After the first trial, immunological, hematological and biochemical parameters, intestinal morphology and the growth performance were assessed, whereas in the second trial, immunological, hematological and biochemical parameters were assessed. Supplementation of diets with ACT showed a significant effect mainly after 60 days of feeding, with increased lysozyme, globulin, HTC, MCV, erythroblasts, leukocytes, lymphocytes and monocytes. A general decrease in cells and globulin occurred at 5 days after the LPS challenge, with partial recovery at 12 days after the challenge. In addition, the study demonstrated that the use of ACT, an extract derived from yeast cell walls and containing
\end{abstract}

Jaqueline Dalbello Biller-Takahashi

biller@dracena.unesp.br

Natalia Ha

natalinha_kr@hotmail.com

André Fernando Nascimento Gonçalves

andre@zootecnista.com.br

Luana Camargo Sousa

luanacamargo.bio@hotmail.com

Leonardo Susumu Takahashi

takahashi@dracena.unesp.br

1 Faculdade de Ciências Agrárias e Tecnológicas, UNESP Univ Estadual Paulista, Rod. Cmte João Ribeiro de Barros, km 651, Dracena, SP 17900-000, Brazil 
active mannan protein and carbohydrates, effectively increased the immune parameters evaluated, indicating a possible beneficial effect on fish health.

Keywords Immunostimulant $\cdot$ Prebiotic $\cdot$ Fish $\cdot$ Endotoxin $\cdot$ Actigen

$\begin{array}{ll}\text { Abbreviations } \\ \text { ACT } & \text { Actigen } \\ \text { LPS } & \text { Lipopolysaccharide } \\ \text { ACP50 } & \text { Alternative complement pathway } \\ \text { OD } & \text { Optical density } \\ \text { NBT } & \text { Nitroblue tetrazolium } \\ \text { DMF } & \text { Dimethylformamide } \\ \text { RBC } & \text { Red blood cell } \\ \text { HGB } & \text { Hemoglobin } \\ \text { HTC } & \text { Hematocrit } \\ \text { MCV } & \text { Mean corpuscular volume } \\ \text { MCHC } & \text { Mean corpuscular hemoglobin concentration } \\ \text { WBC } & \text { White blood cell } \\ \text { A:G } & \text { Albumin:globulin } \\ \text { AFW } & \text { Average final weight } \\ \text { WG } & \text { Weight gain } \\ \text { DWG } & \text { Daily weight gain } \\ \text { SGR } & \text { Specific growth rate } \\ \text { FC } & \text { Feed consumption } \\ \text { DFC } & \text { Daily feed consumption } \\ \text { AFC } & \text { Apparent feed conversion } \\ \text { PBS } & \text { Phosphate-buffered saline }\end{array}$

\section{Introduction}

The Nile tilapia (Oreochromis niloticus) is considered one of the most important fish produced in Brazil and worldwide due to its excellent growth and reproductive performance (Yassui et al. 2007). The intensification of the fish production systems has generated numerous stress factors, due to higher stocking densities, changes in water quality, increased organic load and excessive fish handling (Barton 2000). These stressors result in immunosuppression, decrease in growth performance and increase in susceptibility to diseases caused by pathogenic microorganisms, such as bacteria, which has a rapid proliferation in aquatic environments and is responsible for major losses in global aquaculture and antibiotics misuses (Tort 2011).

Most of the diseases in fish are caused by Gram-negative bacteria, due to the presence of lipopolysaccharide (LPS) as a structural component of the cell wall (Wright et al. 1990). Different Gram-negative bacteria are part of the microbiota, water, skin, gills and intestine of fish, for example, the genus Aeromonas, Plesiomonas, Pseudomonas and Vibrio, which are considered as opportunistic, and when there is an imbalance of bacteria-host ambient systems, it may trigger diseases outbreaks (Toranzo et al. 1989). As a result, isolated bacterial LPS from Escherichia coli has been used to promote inflammation (Djordjevic 
et al. 2009; Haukenes and Barton 2004; Martins et al. 2008) and immunomodulation in fish (Wright et al. 1990; Swain et al. 2008).

As a result, the use of immunostimulants such as the compounds extracted from the cell wall of Saccharomyces cerevisiae has been a good alternative for inducing the immune response (Trichet 2010). However, the administration of this immunostimulant requires knowledge on the optimum dose for each fish species, as well as the period of supplementation in different production conditions (Mahious et al. 2006; Ridha and Azad 2015; Torrecillas et al. 2014).

Actigen $^{\circledR}$ (ACT, Alltech, Nickolasville, KY, USA) is a prebiotic containing active fractions of mannan-rich carbohydrates and proteins. It was developed using nutrigenomics technologies to improve growth performance and intestinal health via its role in immunomodulation. This is a yeast derivative compound that presents an elevated concentration of active mannan protein with higher biological activity than the first-generation product (Bio-MOS ${ }^{\circledR}$; Hooge and Connolly 2011; Maldarasanu et al. 2013; Sara et al. 2012).

Despite the countless perceived beneficial effects, there is a lack of information on the effects of ACT in fish (Hung 2012). Based on the positive results regarding growth performance and immunity that were obtained with the first-generation product (Bio-MOS ${ }^{\circledR}$ ), the aim of this study was to evaluate the physiological and immunological responses and productive performance in the Nile tilapia fed with different concentrations of ACT after LPS challenge.

\section{Materials and methods}

\section{Fish, experimental diets and protocols}

A total of 288 juveniles of Nile tilapia were distributed into 24 polythene boxes, 12 animals per box, six boxes for each treatment. Each box had a capacity of $130 \mathrm{~L}$ and was arranged in an open circulation system provided with continuous water and forced aeration. A constant temperature was maintained (approximately $26^{\circ} \mathrm{C}$ ) by heating with thermostats, and a natural photoperiod ( $12 \mathrm{~h}$ light: $12 \mathrm{~h}$ dark) was established. The water flow in the tanks was approximately $2-2.5 \mathrm{~L} \mathrm{~min}^{-1}$, and the water quality parameters of the boxes were monitored daily using portable meters. Water quality parameters remained within the range considered optimal for the species: dissolved oxygen $\left(5.8 \pm 1.4 \mathrm{mg} \mathrm{dL}^{-1}\right)$, temperature $\left(26 \pm 1.4{ }^{\circ} \mathrm{C}\right)$ and $\mathrm{pH}(7.7 \pm 0.6$; Lim and Webster 2006). Feed and fish feces which remained in the boxes were removed daily.

The fish were acclimated to laboratory conditions for 30 days in polyethylene boxes and fed four times a day with the control diet (0\% ACT) ad libitum, with feed intake measured daily. The ACT was added within the experimental diets at 0, 0.04, 0.06 and $0.08 \%$ concentrations in a practical diet formulated for the nutritional requirements of the species, as shown in Table 1. The ingredients were ground in a hammer mill ( $0.8 \mathrm{~mm}$ sieve), mixed, pelleted after water was added $(30 \%)$ and baked in the oven at $45{ }^{\circ} \mathrm{C}$ for $48 \mathrm{~h}$. Diets were stored in plastic containers and refrigerated $\left(4{ }^{\circ} \mathrm{C}\right)$ throughout the experiment. This study was approved by the Ethics Committee on Animal Use of Universidade Estadual Paulista "Júlio de Mesquita Filho"_-UNESP (Protocol Number 21/2014). 
Table 1 Ingredients and chemical composition of the experimental diets

\begin{tabular}{|c|c|c|c|c|}
\hline & \multicolumn{4}{|l|}{ Diets } \\
\hline & Control & $0.04 \%$ & $0.06 \%$ & $0.08 \%$ \\
\hline \multicolumn{5}{|l|}{ Ingredients } \\
\hline Soybean meal & 37.0 & 37.0 & 37.0 & 37.0 \\
\hline Corn & 26.7 & 26.7 & 26.7 & 26.7 \\
\hline Wheat bran & 22.6 & 22.5 & 22.5 & 22.5 \\
\hline Fish meal & 8.00 & 8.00 & 8.00 & 8.00 \\
\hline Dicalcium phosphate & 2.30 & 2.30 & 2.30 & 2.30 \\
\hline Soy oil & 1.00 & 1.00 & 1.00 & 1.00 \\
\hline Premix $^{a}$ & 1.40 & 1.40 & 1.40 & 1.40 \\
\hline Sodium chloride & 1.00 & 1.00 & 1.00 & 1.00 \\
\hline Actigen $^{\mathrm{b}}$ & 0.00 & 0.04 & 0.06 & 0.08 \\
\hline Total & 100 & 100 & 100 & 100 \\
\hline \multicolumn{5}{|l|}{ Calculated nutritional composition } \\
\hline Dry matter $(\%)$ & 88.9 & 88.8 & 88.8 & 88.8 \\
\hline Crude protein $(\%)$ & 26.8 & 26.8 & 26.8 & 26.8 \\
\hline Digestible protein $^{\mathrm{c}}(\%)$ & 24.1 & 24.1 & 24.1 & 24.1 \\
\hline Lipid $(\%)$ & 3.95 & 3.95 & 3.95 & 3.95 \\
\hline Crude fiber $(\%)$ & 5.44 & 5.44 & 5.44 & 5.44 \\
\hline Ash $(\%)$ & 8.89 & 8.88 & 8.88 & 8.88 \\
\hline Nitrogen-free extract ${ }^{\mathrm{d}}(\%)$ & 43.5 & 43.5 & 43.5 & 43.5 \\
\hline Gross energy $\left(\mathrm{kcal} \mathrm{kg}^{-1}\right)$ & 3910 & 3910 & 3910 & 3910 \\
\hline Digestible energy $^{\mathrm{c}}\left(\mathrm{kcal} \mathrm{kg}^{-1}\right)$ & 2970 & 2970 & 2970 & 2970 \\
\hline
\end{tabular}

a Enrichment per kilogram of feed: Vit. A-3000 UI; Vit. D3-3000 UI; Vit. E-200.00 mg; Vit. B1$6.00 \mathrm{mg}$; Vit. B2-8.00 mg; Vit. B6-3.00 mg; Vit. B12-20.00 mg; Vit. C-350.00 mg; Vit. K$6.00 \mathrm{mg}$; folic acid-1.00 mg; pantothenic acid-20.00 mg; biotin-0.10 mg; copper-10.00 mg; iron$100.00 \mathrm{mg}$; iodine $-5.00 \mathrm{mg}$; manganese $-70.00 \mathrm{mg}$; niacin-100.00 mg; zinc-150.00 mg; B.H.T.— $125.00 \mathrm{mg}$; colin-150.00 mg

b Actigen $^{\circledR}$ (ACT) Alltech, Nickolasville, KY, USA

c Estimated value according to Abimorad and Carneiro (2004)

${ }^{\mathrm{d}}$ Nitrogen-free extract $=$ dry matter - crude protein - lipid - crude fiber - ash

\section{Trial 1: Experimental design}

The first experimental trial was conducted to evaluate the best period of ACT administration and the optimal ACT concentrations required to determine the effects of immunostimulant on the nonspecific immune system and on hematological and biochemical parameters of juvenile Nile tilapia. The trial used 288 juveniles with an initial weight and total length of $38.4 \pm 0.26 \mathrm{~g}$ and $12.73 \pm 0.89 \mathrm{~cm}$, respectively (mean $\pm \mathrm{SD}$ ). The fish were fed the experimental diets for 30 and 60 days to apparent satiation, in four meals per day (0900, 1200, 1500 and 1800 hours).

After 30 and 60 days of the experimental trial, two fish were sampled from each box (six boxes for treatment; $n=12$ fish per treatment) at each time point and used for blood collection via venipuncture of the caudal vessel. Syringes without anticoagulant were used to obtain serum, which was analyzed to determine the concentration of lysozyme activity 
level, complement hemolytic activity, total protein, albumin and globulin levels. To obtain whole blood, microtubes with anticoagulant (heparin) were used for blood storage. Whole blood was analyzed to determine the leukocyte respiratory burst activity and to acquire a complete hemogram with measurement of hematocrit, red blood cells, hemoglobin concentration, hematological indexes: mean corpuscular hemoglobin (MCHC), mean corpuscular hemoglobin $(\mathrm{MCH})$, mean corpuscular volume (MCV), and total and differential counts of leukocytes.

\section{Immunological, hematological and biochemical parameters}

The lysozyme activity level was determined through the turbidimetric assay described by Ellis (1990), in which lyophilized hen egg white lysozyme (Sigma, St. Louis, MO, USA) was applied to construct a standard curve. To evaluate the lysozyme level, a solution of $20 \mathrm{mg}$ of Micrococcus lysodeikticus (Sigma, St. Louis, MO, USA) in $100 \mathrm{~mL}$ sodium phosphate buffer $(0.05 \mathrm{M}, \mathrm{pH} 6.2)$ was used. The assay was initiated in a microplate at a dilution of $1: 1$ ( $50 \mu \mathrm{L}$ of phosphate buffer:50 $\mu \mathrm{L}$ of serum), and twofold serial serum dilutions were made by adding $50 \mu \mathrm{L}$ of diluted serum into the remaining wells filled with $50 \mu \mathrm{L}$ of PBS. A volume of $125 \mu \mathrm{L}$ of $M$. lysodeikticus was then added to each well. The reaction was performed at $25{ }^{\circ} \mathrm{C}$, and the absorbance was measured at $450 \mathrm{~nm}$ after 0.5 and $5.0 \mathrm{~min}$ in a microplate reader (Benchmark, Bio-Rad, USA). The results were expressed in units of lysozyme per $\mathrm{mL}$ of serum. One unit is defined as the amount of sample required to reduce absorbance of $0.001 / \mathrm{min}$ at $450 \mathrm{~nm}$ compared to the control $(M$. lysodeikticus suspension without serum).

The hemolytic complement activity was assessed using the alternative complement pathway (ACP50) according to Biller-Takahashi et al. (2012). An aliquot of whole blood of rabbits was mixed with the same volume of Alsever's solution and the resulting solution filtered to remove suspended material. It was added to the filtered solution the chelating agent TEA-EDTA (triethanolamine-ethylene diaminetetraacetic acid) and gelatin, and this solution was incubated at $37{ }^{\circ} \mathrm{C}$ and centrifuged to separate the erythrocytes. The hemolytic activity of complement was performed by mixing $200 \mu \mathrm{L}$ of each dilution of serum to $400 \mu \mathrm{L}$ of erythrocyte suspension which was subjected to reading absorbance at $700 \mathrm{~nm}$ for $10 \mathrm{~min}$, kinetic spectrophotometer. Then, $60 \mu \mathrm{L}$ of serum fish of all treatments, at 1:10 dilution, was added to $140 \mu \mathrm{L}$ of TEA-EGTA buffer $8 \mathrm{mM}$ and $\mathrm{Mg}^{2+} 2 \mathrm{mM}, 0.1 \%$ gelatin, and to this mixture was added $400 \mu \mathrm{L}$ of the suspension of erythrocytes. The solution was then subjected to reading in spectrophotometer ELISA type. The value of $50 \%$ hemolysis was calculated from the hemolysis curves of diluted sera.

The assay for the leukocyte respiratory burst activity was carried out according to Biller-Takahashi et al. (2013). Total blood was collected from the caudal vessel of fish from each treatment, and $0.1 \mathrm{~mL}$ of heparinized blood was added to $0.1 \mathrm{~mL}$ of $0.2 \%$ nitroblue tetrazolium (NBT, Sigma, St Louis, MO, USA). The solution was incubated for $30 \mathrm{~min}$ at $25^{\circ} \mathrm{C}$. After incubation, $50 \mu \mathrm{L}$ of the resulting suspension was added to a glass

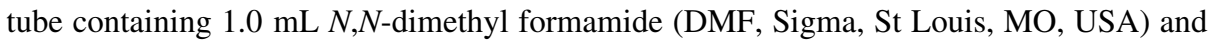
centrifuged at $2500 \times \mathrm{g}$ for $5 \mathrm{~min}$. The optical density (OD) of the final solution was measured at $540 \mathrm{~nm}$.

The total red blood cells (RBCs) were determined using the improved Neubauer counting chamber, the hemoglobin (HGB) content was assayed by cyanomethaemoglobin determination, and the hematocrit (HTC) was standardized using the microhematocrit method. Wintrobe indexes such as the mean corpuscular volume (MCV) and mean corpuscular hemoglobin concentration $(\mathrm{MCHC})$ were derived from the primary indexes 
(Wintrobe 1934). The white blood cell (WBC) count and the differential leukocyte count were determined from blood smears stained with May-Grünwald-Giemsa (Rosenfeld 1947). The total leukocyte number was calculated using the following formula: leukocytes/ $\mu \mathrm{L}=($ leukocyte number in the smear $\times$ erythrocyte number $/ \mu \mathrm{L}) / 2000$ erythrocytes counted in the smear.

The total serum protein levels were determined using the biuret method (Labtest Kit; Reinhold 1953), and the albumin concentration was evaluated using the bromocresol green binding colorimetric assay (Labtest Kit; Doumas et al. 1971). The amount of globulin present in the samples was established by subtracting the albumin from the total serum protein, and the globulin-albumin ratio (A:G) was calculated by dividing the value of the albumin fraction by that of the globulin fraction for each tested sample.

\section{Morphometry of the intestine}

The histological analysis of the intestine was carried out in two fish from each box (12 fish per treatment), after 30 and 60 days of feeding with the experimental diets. Fish were

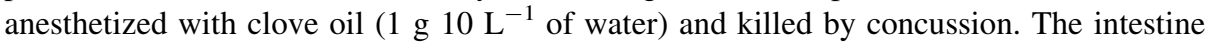
was exposed in a Petri dish and divided into three parts: anterior, middle and distal. Two centimeters of the anterior and distal intestine was opened longitudinally to expose the villi. Each sample was set in Bouin solution for $12 \mathrm{~h}$, dehydrated with a progressive series of alcohol solutions, diaphanized in xylene, embedded in paraffin and sliced into sections, six microns wide. Samples were stained with hematoxylin-eosin, observed with an optical microscope OptiCam $(10 \times)$ and photographed (digital camera Moticam 2300, 3 MP). Total height, width and thickness of the villi were measured using an image analyzer (ToupTek ToupView software-x64 version 7.3.2270, with a resolution of $3264 \times 2448$ ).

\section{Growth performance}

After 30 and 60 days of feeding, all fish were sampled to evaluate growth performance. Fish were exposed to $24 \mathrm{~h}$ of fasting and then anesthetized in clove oil solution $(1 \mathrm{~g}$ $10 \mathrm{~L}^{-1}$ of water) and individually weighed and measured. The following performance parameters were calculated and evaluated according to Tacon (1990): average final weight (AFW), weight gain (WG), daily weight gain (DWG), specific growth rate (SGR), feed consumption (FC), daily feed consumption (DFC), apparent feed conversion (AFC) and mortality.

\section{Trial 2: Experimental design}

The second experiment was conducted to evaluate the physiological and immunological responses and productive performance in the Nile tilapia fed during 60 days with ACT after LPS challenge, in the remaining fish of Trial 1. Subsequently, after 60 days of ACT supplementation in the diet, the animals were anesthetized with clove oil $\left(1 \mathrm{~g} 10 \mathrm{~L}^{-1}\right.$ of water) and challenged by intraperitoneal injection of $0.1 \mathrm{~mL}$ of LPS solution $\left(500 \mu \mathrm{g} \mathrm{kg}^{-1}\right.$ of fish, extracted from E. coli 026:B6, Sigma, St. Louis, MO, USA) dissolved in PBS buffer. Subsequent to LPS challenge, fish stopped receiving diets with Actigen ${ }^{\circledR}$. At 5 and 12 days after the challenge, blood was collected for further analysis, and the mortality was observed throughout the period (Selvaraj et al. 2006). 


\section{Immunological, hematological and biochemical parameters}

At 5 and 12 days after the LPS challenge, two fish were taken from each box (12 fish per treatment) and submitted for blood collection via venipuncture of the caudal vessel. Syringes without anticoagulant were used to obtain serum, which was analyzed to determine the concentration of lysozyme, complement hemolytic activity, total protein and albumin. To obtain whole blood, microtubes with anticoagulant (heparin) were used for the storage of blood. This whole blood was analyzed to determine the leukocyte respiratory burst activity and to obtain a complete hemogram with measurement of RBC, HGB, HTC, hematimetric indexes, and total and differential counts of leukocytes.

\section{Statistical analysis}

The experimental unit considered was the tank corresponded by the average of all fish per tank in growth performance and two fish per tank in all the other parameters. Data were analyzed by two-way analysis of variance (ANOVA) followed by a Tukey's test for comparisons of means $(P<0.05)$. The normal distribution of the data and the homogeneity of variances among treatments were verified before the ANOVA was performed. Polynomial regression analysis was used to estimate the optimum dietary Actigen supplementation based on lysozyme activity. All statistical analyses were performed using SAS (statistical analysis system, version 9.0, Cary, NC, USA).

\section{Results}

\section{Trial 1}

Immunological, hematological and biochemical parameters, morphometry and growth performance

The activity of lysozyme was higher $(P<0.05)$ for the fish fed for 60 days, independent of the diet (Fig. 1). However, the hemolytic activity of the complement was higher in fish fed experimental diets for 30 days $(P<0.05)$, independent of the concentration of ACT

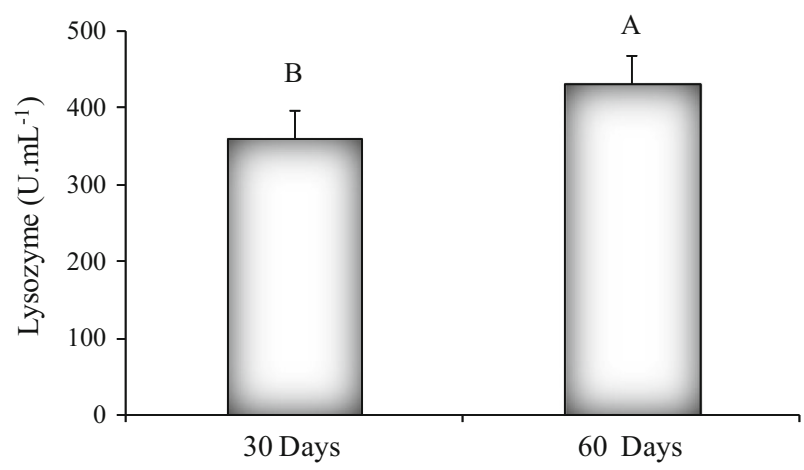

Fig. 1 Lysozyme activity of serum (mean \pm SEM) from Nile tilapia fed Actigen, in Trial 1. Bars marked with different letters are significantly different (pooled SEM $=14.1 \mathrm{U} \mathrm{mL}^{-1} ; P=0.0034 ; n=12$ ) 
Table 2 Immunological and hematological parameters of Nile tilapia fed with different concentrations of Actigen evaluated at 30 and 60 days of the experiment, in Trial 1

\begin{tabular}{|c|c|c|c|c|c|c|c|c|c|c|}
\hline & \multirow[t]{2}{*}{ Days } & \multicolumn{5}{|c|}{ Actigen (\%) } & \multirow{2}{*}{$\begin{array}{l}\text { Pooled } \\
\text { SEM }\end{array}$} & \multicolumn{3}{|c|}{$P$ value } \\
\hline & & 0 & 0.04 & 0.06 & 0.08 & Mean & & $\mathrm{C}$ & $\mathrm{T}$ & $\mathrm{C} \times \mathrm{T}$ \\
\hline \multirow[t]{3}{*}{$\mathrm{ACP}\left(\mathrm{U} \mathrm{mL}^{-1}\right)$} & 30 & 313 & 484 & 472 & 283 & $392 \mathrm{~A}$ & & & & \\
\hline & 60 & 245 & 329 & 251 & 205 & $260 \mathrm{~B}$ & 29.8 & 0.1644 & 0.0297 & 0.7638 \\
\hline & Mean & 188 & 406 & 361 & 244 & & & & & \\
\hline \multirow[t]{3}{*}{ Burst (DO) } & 30 & 0.27 & 0.30 & 0.35 & 0.32 & $0.3 \mathrm{~A}$ & & & & \\
\hline & 60 & 0.22 & 0.26 & 0.25 & 0.28 & $0.25 \mathrm{~B}$ & 0.01 & 0.0004 & 0.0001 & 0.0739 \\
\hline & Mean & $0.24 \mathrm{~b}$ & $0.28 \mathrm{ab}$ & $0.30 \mathrm{a}$ & $0.30 \mathrm{a}$ & & & & & \\
\hline \multirow{3}{*}{$\begin{array}{l}\text { RBC } \\
\qquad\left(\times 10^{6} \mathrm{~mm}^{-3}\right)\end{array}$} & 30 & 2.30 & 2.68 & 2.49 & 2.85 & $2.66 \mathrm{~A}$ & & & & \\
\hline & 60 & 2.08 & 2.35 & 2.31 & 2.38 & $2.37 \mathrm{~B}$ & 0.05 & 0.0073 & 0.0009 & 0.6448 \\
\hline & Mean & $2.24 \mathrm{~b}$ & $2.56 \mathrm{ab}$ & $2.45 \mathrm{ab}$ & $2.67 \mathrm{a}$ & & & & & \\
\hline \multirow[t]{3}{*}{$\mathrm{HGB}\left(\mathrm{g} \mathrm{dL}^{-1}\right)$} & 30 & 7.81 & 10.1 & 9.81 & 11.1 & $9.70 \mathrm{~A}$ & & & & \\
\hline & 60 & 6.07 & 6.69 & 8.30 & 8.44 & $7.37 \mathrm{~B}$ & 0.03 & 0.0003 & 0.0001 & 0.4160 \\
\hline & Mean & $6.94 \mathrm{~b}$ & $8.39 \mathrm{~b}$ & $9.05 \mathrm{a}$ & $9.77 \mathrm{a}$ & & & & & \\
\hline \multirow[t]{3}{*}{ HTC (\%) } & 30 & 31.9 & 33.4 & 36.2 & 36.2 & $34.4 \mathrm{~B}$ & & & & \\
\hline & 60 & 46.8 & 40.7 & 43.6 & 41.1 & $42.9 \mathrm{~A}$ & 0.84 & 0.4900 & 0.0001 & 0.0541 \\
\hline & Mean & 38.5 & 36.7 & 39.5 & 38.8 & & & & & \\
\hline \multirow[t]{3}{*}{$\operatorname{MCV}\left(\mu^{3}\right)$} & 30 & 144 & 122 & 165 & 127 & $137 \mathrm{~B}$ & & & & \\
\hline & 60 & 200 & 171 & 188 & 186 & $186 \mathrm{~A}$ & 5.22 & 0.0699 & 0.0001 & 0.4796 \\
\hline & Mean & $170 \mathrm{ab}$ & $143 \mathrm{~b}$ & $177 \mathrm{a}$ & $157 \mathrm{ab}$ & & & & & \\
\hline \multirow[t]{3}{*}{$\operatorname{MCHC}\left(\mathrm{g} \mathrm{dL}^{-1}\right)$} & 30 & 24.8 & 29.1 & 27.4 & 31.8 & $28.6 \mathrm{~A}$ & & & & \\
\hline & 60 & 13.7 & 17.6 & 19.9 & 17.6 & $17.3 \mathrm{~B}$ & 1.03 & 0.0704 & 0.0001 & 0.5447 \\
\hline & Mean & 19.6 & 24.3 & 22.8 & 24.7 & & & & & \\
\hline \multirow[t]{3}{*}{$\mathrm{MHC}\left(\mathrm{pg} \mathrm{cel}^{-1}\right)$} & 30 & 37.1 & 37.6 & 40.2 & 50.8 & $41.7 \mathrm{~A}$ & & & & \\
\hline & 60 & 27.3 & 26.0 & 33.5 & 31.7 & $29.8 \mathrm{~B}$ & 1.96 & 0.2304 & 0.0023 & 0.6775 \\
\hline & Mean & 32.2 & 31.5 & 36.4 & 40.8 & & & & & \\
\hline
\end{tabular}

Values followed by different capital letters in the column differ by Tukey's test $(P<0.05)$. Values followed by different small letters on the line differ by Tukey's test $(P<0.05)$

$S E M$ standard error mean, $C$ concentration of Actigen, $T 30$ and 60 days of the treatment, $A C P$ hemolytic activity of alternative complement pathway, $R B C$ red blood cell, $H G B$ hemoglobin, $H T C$ hematocrit, $M C V$ mean corpuscular volume, $M C H C$ mean corpuscular hemoglobin concentration, $M H C$ mean corpuscular hemoglobin

(Table 2). The respiratory activity of leukocytes was not influenced $(P>0.05)$ by ACT supplementation at 30 and 60 days of the experiment. Conversely, for the average of each concentration, the leukocyte respiratory activity responses were higher in the 0.06 and $0.08 \%$ concentrations of ACT groups than the control $(P<0.05)$ (Table 2$)$.

Supplementation of tilapia with ACT at $0.08 \%$ significantly influenced the average of RBC $(P<0.05)$ when compared (independent of time) with the control $(0 \%)$, but was not different $(P>0.05)$ from 0.04 and $0.06 \%$ ACT treatments. Similarly, the HGB in fish fed ACT at 0.06 and $0.08 \%$ was higher than the others treatments. Independent of the ACT, the RBC, the HGB the MCHC and the MCH $(P<0.05)$ were higher after 30 days of feeding with ACT than after 60 days. In contrast, a higher average measurement was observed at 60 days for both HCT and MCV. The mean MCV was significantly different 


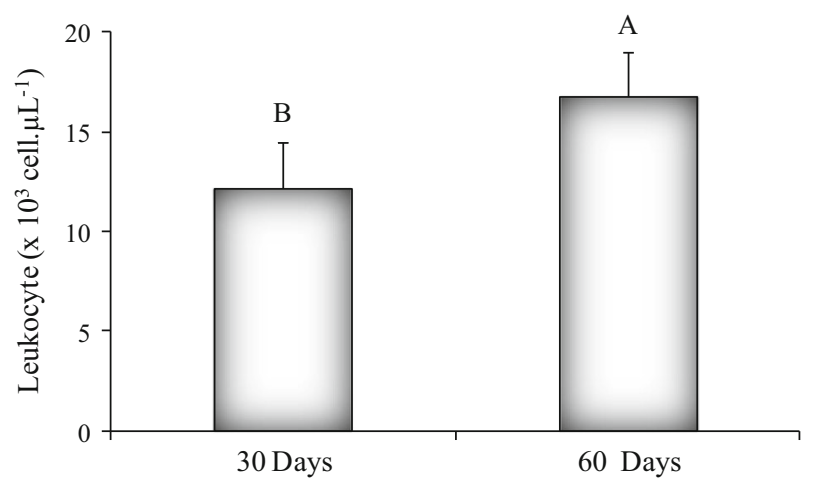

Fig. 2 Leukocytes (mean \pm SEM) from Nile tilapia fed Actigen, in Trial 1. Bars marked with different letters are significantly different (pooled SEM $=8.67$ cell $\mu \mathrm{L}^{-1} ; P=0.0079 ; n=12$ )

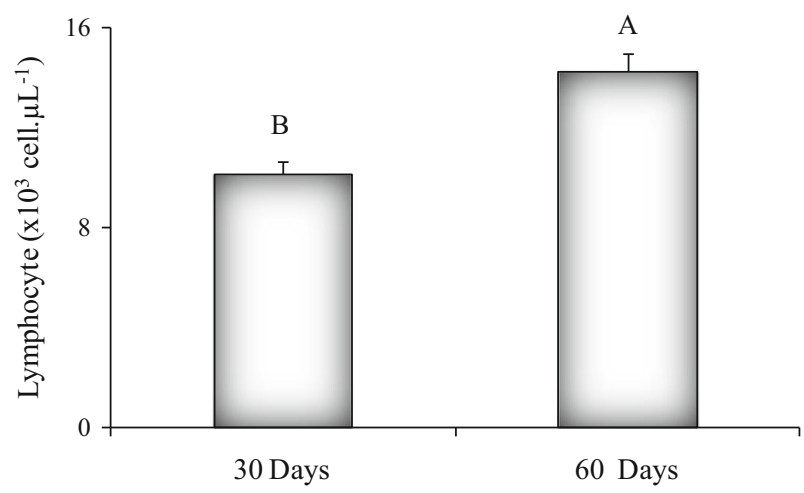

Fig. 3 Lymphocytes (mean \pm SEM) from Nile tilapia fed Actigen, in Trial 1. Bars marked with different letters are significantly different (pooled SEM $=7.57$ cell $\mu \mathrm{L}^{-1} ; P=0.0058 ; n=12$ )

$(P<0.05)$ in the $0.06 \%$ concentration of ACT group when compared to other treatments (Table 2).

The leukocyte (Fig. 2), lymphocyte (Fig. 3), erythroblast and monocyte counts (Table 3$)$ were higher $(P>0.05)$ in fish fed any of the diets for 60 days compared with fish fed any of the diets for 30 days, with the concentration of ACT having no influence on these measures. The total protein and albumin concentration were not influenced by the treatments $(P>0.05)$; however, globulin concentration and the A:G index of fish fed the experimental diets for 60 days were better $(P<0.05)$ than those fed for 30 days with the experimental diets (Table 4).

The total height of the villi of the anterior intestine of fish fed a $0.04 \%$ concentration of ACT was higher than that in the other treatment groups $(P<0.05$; Table 5), but no differences were found in the distal intestine (Table 6). There were no differences $(P>0.05)$ in growth performance among treatments in both periods analyzed (after 30 and 60 days of the experiment) (Table 7 ). 
Table 3 White blood cell from Nile tilapia fed with different concentrations of Actigen evaluated at 30 and 60 days of the experiment, in Trial 1

\begin{tabular}{|c|c|c|c|c|c|c|c|c|c|c|}
\hline & \multirow[t]{2}{*}{ Days } & \multicolumn{5}{|c|}{ Actigen (\%) } & \multirow{2}{*}{$\begin{array}{l}\text { Pooled } \\
\text { SEM }\end{array}$} & \multicolumn{3}{|l|}{$P$ value } \\
\hline & & 0 & 0.04 & 0.06 & 0.08 & Mean & & $\mathrm{C}$ & $\mathrm{T}$ & $\mathrm{C} \times \mathrm{T}$ \\
\hline \multirow{3}{*}{$\begin{array}{l}\text { Erythroblast } \\
\qquad\left(\times 10^{3} \mu \mathrm{L}^{-1}\right)\end{array}$} & 30 & 1.21 & 1.09 & 1.30 & 1.66 & $1.32 \mathrm{~B}$ & & & & \\
\hline & 60 & 2.14 & 3.39 & 2.11 & 2.85 & $2.62 \mathrm{~A}$ & 0.19 & 0.4365 & 0.0001 & 0.1682 \\
\hline & Mean & 1.67 & 2.24 & 1.71 & 2.26 & & & & & \\
\hline \multirow{3}{*}{$\begin{array}{l}\text { Thrombocyte } \\
\qquad\left(\times 10^{3} \mu \mathrm{L}^{-1}\right)\end{array}$} & 30 & 3.22 & 4.11 & 3.13 & 2.33 & 3.20 & & & & \\
\hline & 60 & 2.68 & 3.67 & 4.21 & 2.54 & 3.27 & 0.26 & 0.1759 & 0.8855 & 0.6616 \\
\hline & Mean & 2.95 & 3.89 & 3.67 & 2.43 & & & & & \\
\hline \multirow{3}{*}{$\begin{array}{l}\text { Neutrophil } \\
\qquad\left(\times 10^{3} \mu \mathrm{L}^{-1}\right)\end{array}$} & 30 & 1.07 & 1.59 & 1.06 & 1.58 & 1.32 & & & & \\
\hline & 60 & 0.97 & 0.95 & 1.09 & 1.45 & 1.15 & 0.12 & 0.4367 & 0.3781 & 0.7517 \\
\hline & Mean & 1.02 & 1.27 & 1.07 & 1.51 & & & & & \\
\hline \multirow{3}{*}{$\begin{array}{l}\text { Monocyte } \\
\qquad\left(\times 10^{3} \mu \mathrm{L}^{-1}\right)\end{array}$} & 30 & 0.49 & 0.94 & 0.30 & 0.33 & $0.51 \mathrm{~B}$ & & & & \\
\hline & 60 & 1.40 & 1.00 & 0.92 & 1.02 & $1.08 \mathrm{~A}$ & 0.08 & 0.2515 & 0.0004 & 0.2449 \\
\hline & Mean & 0.94 & 0.97 & 0.61 & 0.67 & & & & & \\
\hline
\end{tabular}

Values followed by different capital letters in the column differ by Tukey's test $(P<0.05)$

$S E M$ standard error mean, $C$ concentration of Actigen, $T 30$ and 60 days of the treatment

Table 4 Biochemical parameters of Nile tilapia fed with different concentrations of Actigen evaluated at 30 and 60 days of the experiment, in Trial 1

\begin{tabular}{|c|c|c|c|c|c|c|c|c|c|c|}
\hline & \multirow[t]{2}{*}{ Days } & \multicolumn{5}{|c|}{ Actigen (\%) } & \multirow{2}{*}{$\begin{array}{l}\text { Pooled } \\
\text { SEM }\end{array}$} & \multicolumn{3}{|l|}{$P$ value } \\
\hline & & 0 & 0.04 & 0.06 & 0.08 & Mean & & $\mathrm{C}$ & $\mathrm{T}$ & $\mathrm{C} \times \mathrm{T}$ \\
\hline \multirow[t]{3}{*}{ Protein $\left(\mathrm{g} \mathrm{dL}^{-1}\right)$} & 30 & 3.17 & 2.92 & 3.33 & 3.67 & 3.29 & & & & \\
\hline & 60 & 4.60 & 4.28 & 4.03 & 4.59 & 4.45 & 0.11 & 0.2359 & 0.0001 & 0.4853 \\
\hline & Mean & 3.93 & 3.65 & 3.65 & 4.15 & & & & & \\
\hline \multirow[t]{3}{*}{ Albumin $\left(\mathrm{g} \mathrm{dL}^{-1}\right)$} & 30 & 1.16 & 1.06 & 1.23 & 1.30 & 1.19 & & & & \\
\hline & 60 & 1.49 & 1.97 & 1.24 & 1.34 & 1.49 & 0.08 & 0.7012 & 0.0490 & 0.2069 \\
\hline & Mean & 1.32 & 1.51 & 1.23 & 1.32 & & & & & \\
\hline \multirow[t]{3}{*}{ Globulin $\left(\mathrm{g} \mathrm{dL}^{-1}\right)$} & 30 & 2.01 & 1.74 & 2.10 & 2.37 & $2.07 \mathrm{~B}$ & & & & \\
\hline & 60 & 3.10 & 3.09 & 3.04 & 3.25 & $3.13 \mathrm{~A}$ & 0.92 & 0.3218 & 0.0001 & 0.7281 \\
\hline & Mean & 2.55 & 2.41 & 2.57 & 2.82 & & & & & \\
\hline \multirow[t]{3}{*}{ A:G index } & 30 & 0.61 & 0.76 & 0.66 & 0.56 & $0.64 \mathrm{~A}$ & & & & \\
\hline & 60 & 0.46 & 0.64 & 0.37 & 0.45 & $0.48 \mathrm{~B}$ & 0.12 & 0.8900 & 0.0001 & 0.7103 \\
\hline & Mean & 0.53 & 0.71 & 0.50 & 0.50 & & & & & \\
\hline
\end{tabular}

Values followed by different capital letters in the column differ by Tukey's test $(P<0.05)$

SEM standard error mean, $C$ concentration of Actigen, $T 30$ and 60 days of the treatment, $A: G$ albumin:globulin 
Table 5 Morphology of anterior intestine from Nile tilapia fed with different concentrations of Actigen evaluated at 30 and 60 days of the experiment, in Trial 1

\begin{tabular}{|c|c|c|c|c|c|c|c|c|c|c|}
\hline \multirow[t]{2}{*}{ Anterior } & \multirow[t]{2}{*}{ Days } & \multicolumn{5}{|c|}{ Actigen $(\%)$} & \multirow{2}{*}{$\begin{array}{l}\text { Pooled } \\
\text { SEM }\end{array}$} & \multicolumn{3}{|l|}{$P$ value } \\
\hline & & 0 & 0.04 & 0.06 & 0.08 & Mean & & $\mathrm{C}$ & $\mathrm{T}$ & $\mathrm{C} \times \mathrm{T}$ \\
\hline \multirow{3}{*}{$\begin{array}{l}\text { Total height } \\
(\mu \mathrm{m})\end{array}$} & 30 & 276 & 392 & 289 & 236 & 298 & & & & \\
\hline & 60 & 271 & 330 & 305 & 245 & 288 & 14.7 & 0.0318 & 0.0707 & 0.7551 \\
\hline & Mean & $273 \mathrm{~B}$ & $361 \mathrm{~A}$ & $297 \mathrm{AB}$ & $240 \mathrm{~B}$ & & & & & \\
\hline \multirow{3}{*}{$\begin{array}{l}\text { Thickness } \\
(\mu \mathrm{m})\end{array}$} & 30 & 43.8 & 52 & 51.2 & 48.2 & 48.8 & & & & \\
\hline & 60 & 51.3 & 57.1 & 51.6 & 45.3 & 51.3 & 3.01 & 0.1799 & 0.3715 & 0.5477 \\
\hline & Mean & 47.5 & 54.5 & 51.4 & 46.8 & & & & & \\
\hline \multirow[t]{3}{*}{ Width $(\mu \mathrm{m})$} & 30 & 110 & 144 & 133 & 122 & 127 & & & & \\
\hline & 60 & 135 & 140 & 127 & 124 & 131 & 1.39 & 0.0624 & 0.485 & 0.1859 \\
\hline & Mean & 123 & 142 & 130 & 123 & & & & & \\
\hline
\end{tabular}

Values followed by different letters in the line differ by Tukey's test $(P<0.05)$

$S E M$ standard error mean, $C$ concentration of Actigen, $T 30$ and 60 days of the treatment

Table 6 Morphology of distal intestine from Nile tilapia fed with different concentrations of Actigen evaluated at 30 and 60 days of the experiment, in Trial 1

\begin{tabular}{|c|c|c|c|c|c|c|c|c|c|c|}
\hline \multirow[t]{2}{*}{ Distal } & \multirow[t]{2}{*}{ Days } & \multicolumn{5}{|c|}{ Actigen (\%) } & \multirow[t]{2}{*}{ Pooled SEM } & \multicolumn{3}{|l|}{$P$ value } \\
\hline & & 0 & 0.04 & 0.06 & 0.08 & Mean & & $\mathrm{C}$ & $\mathrm{T}$ & $\mathrm{C} \times \mathrm{T}$ \\
\hline \multirow[t]{3}{*}{ Total height $(\mu \mathrm{m})$} & 30 & 152 & 171 & 176 & 215 & 179 & & & & \\
\hline & 60 & 171 & 245 & 218 & 254 & 222 & 10.97 & 0.1168 & 0.0452 & 0.8203 \\
\hline & Mean & 162 & 208 & 197 & 235 & & & & & \\
\hline \multirow[t]{3}{*}{ Thickness $(\mu \mathrm{m})$} & 30 & 38.9 & 42.1 & 45.2 & 46.9 & 43.2 & & & & \\
\hline & 60 & 39.7 & 43.1 & 40.3 & 45.3 & 42.1 & 1.17 & 0.3269 & 0.0514 & 0.6552 \\
\hline & Mean & 39.3 & 42.6 & 42.7 & 46 & & & & & \\
\hline \multirow[t]{3}{*}{ Width $(\mu \mathrm{m})$} & 30 & 114 & 117 & 134 & 129 & 123 & & & & \\
\hline & 60 & 97.8 & 117 & 110 & 114 & 109 & 3.50 & 0.2823 & 0.6428 & 0.8022 \\
\hline & Mean & 106 & 117 & 122 & 121 & & & & & \\
\hline
\end{tabular}

$S E M$ standard error mean, $C$ concentration of Actigen, $T 30$ and 60 days of the treatment

\section{Trial 2}

Immunological, hematological and biochemical parameters and growth performance

Lysozyme activity was increased at 5 days after challenge compared to other time periods, except in the concentration of $0.08 \%(P<0.05)$, and polynomial regression analysis indicated that the optimum level of ACT could be approximately $0.02 \%$ of ACT of diets for tilapia $(P=0.0169$; Fig. 4$)$. An increased production of reactive oxygen species was observed at 5 days after challenge with LPS $(P>0.05)$, independent of ACT concentration (Table 8$)$. RBC and HCT were not affected by ACT treatments $(P>0.05)$. However, the HGB and MCH were higher $(P<0.05)$ at 5 and 12 days after the LPS challenge when 
Table 7 Growth performance from Nile tilapia fed with different concentrations of Actigen evaluated at 30 and 60 days of the experiment, in Trial 1

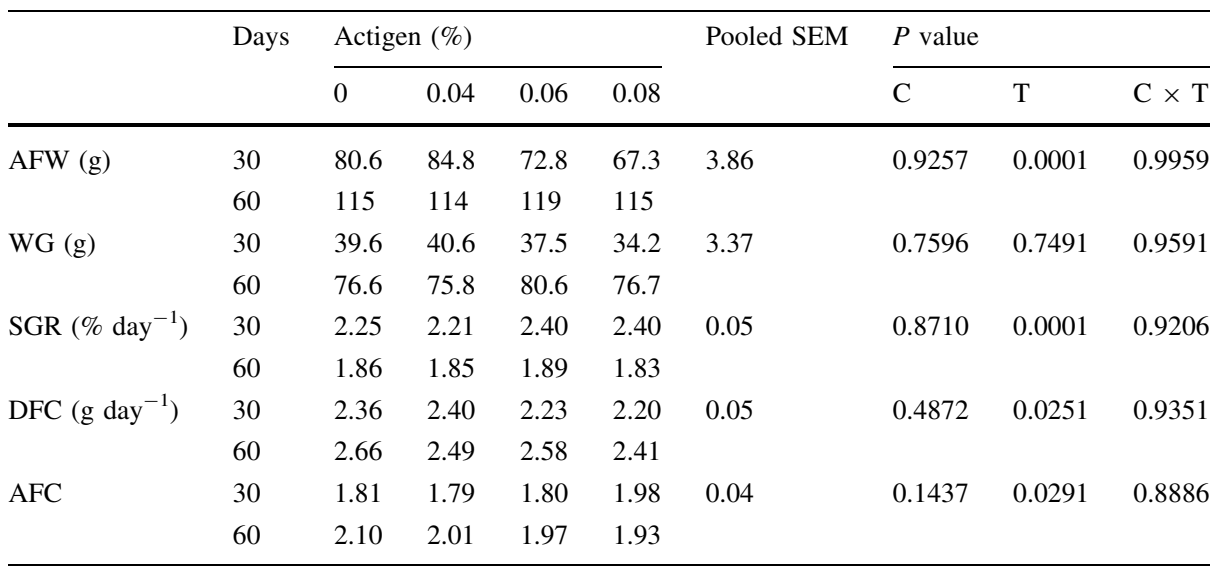

SEM standard error mean, $C$ concentration of Actigen, $T 30$ and 60 days of the treatment, $A F W$ average final weight, $W G$ weight gain, $S G R$ specific growth rate, $D F C$ daily feed consumption, $A F C$ apparent feed conversion

Fig. 4 Serum bactericidal activity (mean $\pm \mathrm{SE}$ ) of Nile tilapia fed Actigen for 60 days $(P=0.0169)$, in Trial 1

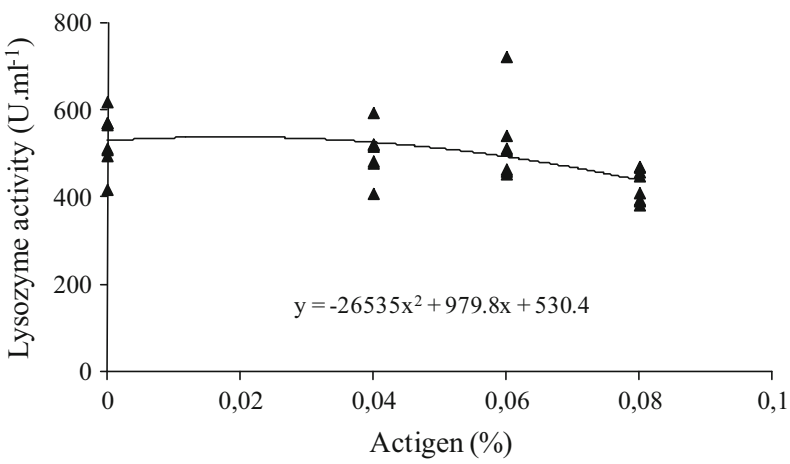

compared with the control. The opposite was observed for the MCV, with lower values at 5 and 12 days after challenge. MCHC was highest $(P<0.05)$ at 12 days post-challenge, followed by values obtained at 5 days post-challenge when compared to the control (Table 8).

Erythroblast counts were lower $(P<0.05) 12$ days after LPS challenge when compared with the other treatments. The leukocyte and lymphocyte counts were lower at 5 days after challenge, with relatively higher values at 12 days post-challenge when compared to the control, independent of treatment with ACT. Thrombocyte counts were lower $(P<0.05)$ at 5 days after challenge when compared to other treatments. A significant neutropenia was observed $(P<0.05)$ after LPS challenge at 5 and at 12 days $(P<0.05)$ independent of the concentration of ACT (Table 9).

The total protein values and the A:G index showed improved values $(P<0.05)$ at 12 days after LPS challenge. An opposite profile was observed in serum albumin and A:G index with lower levels $(P<0.05)$ at 12 days post-challenge in all treatments. Regarding 


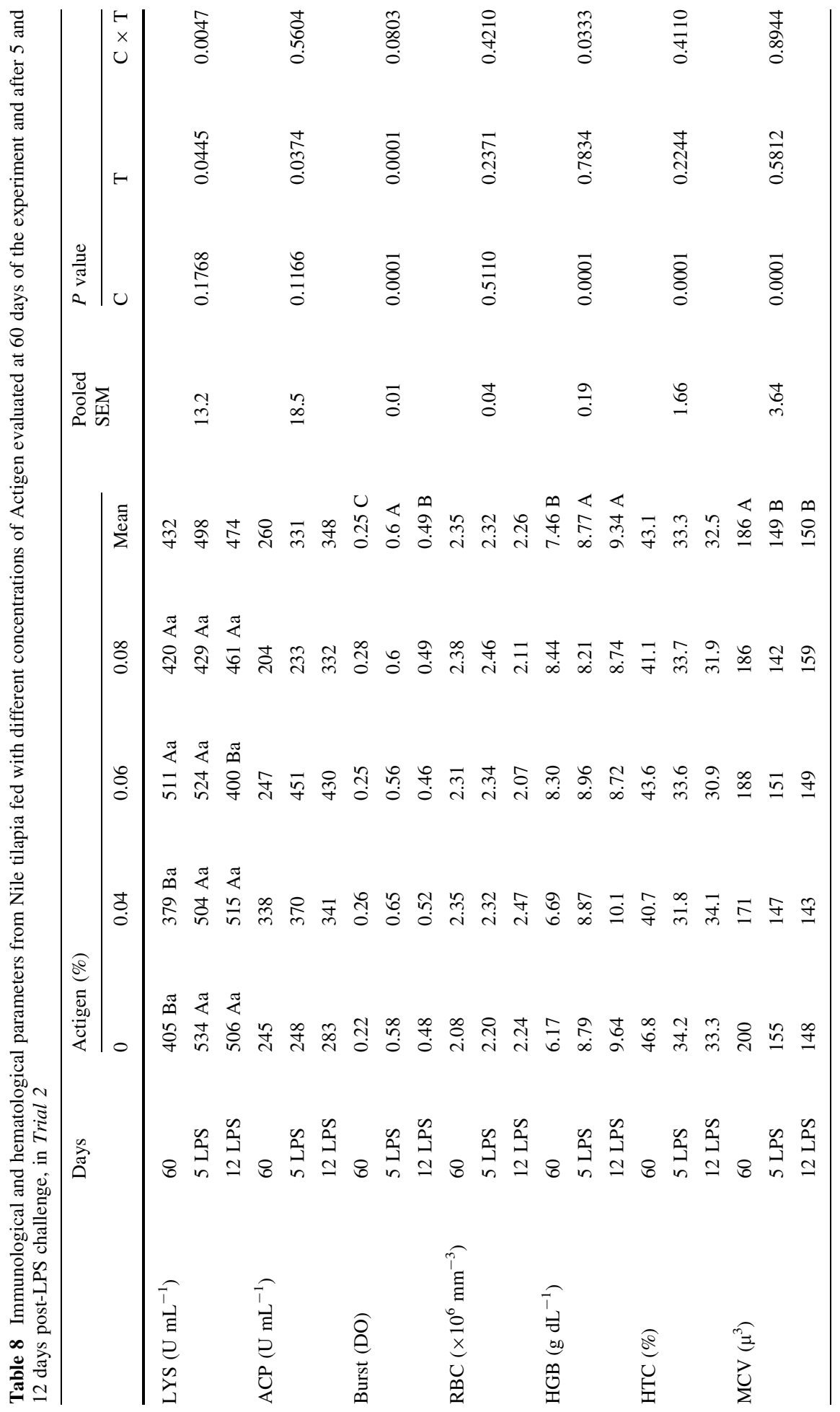




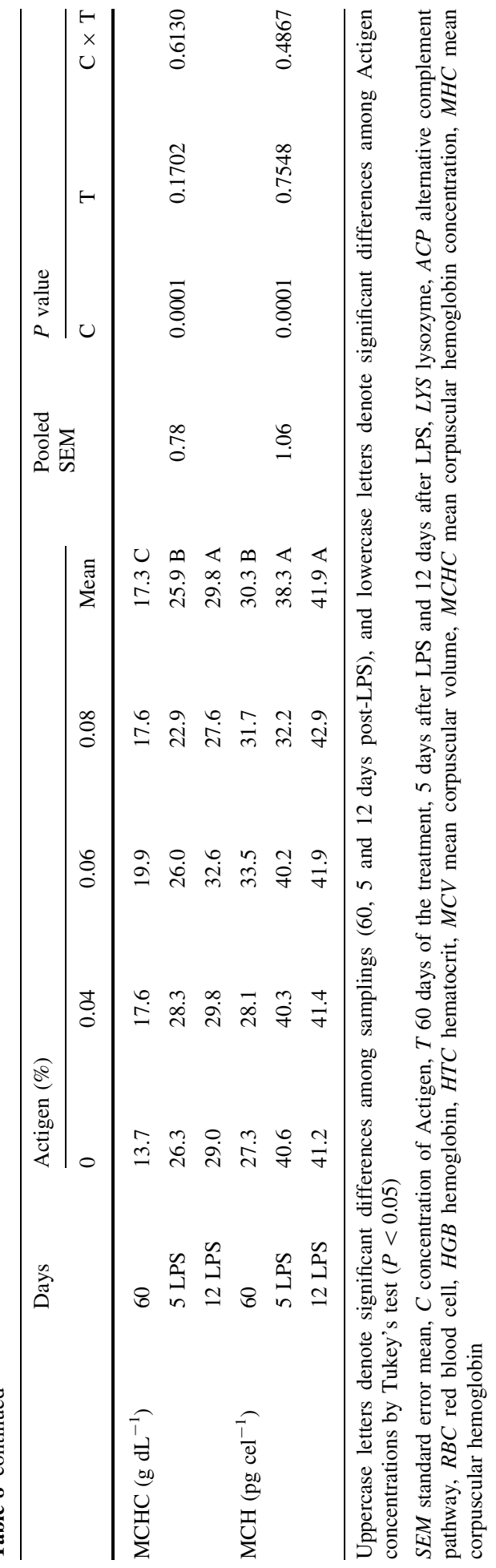




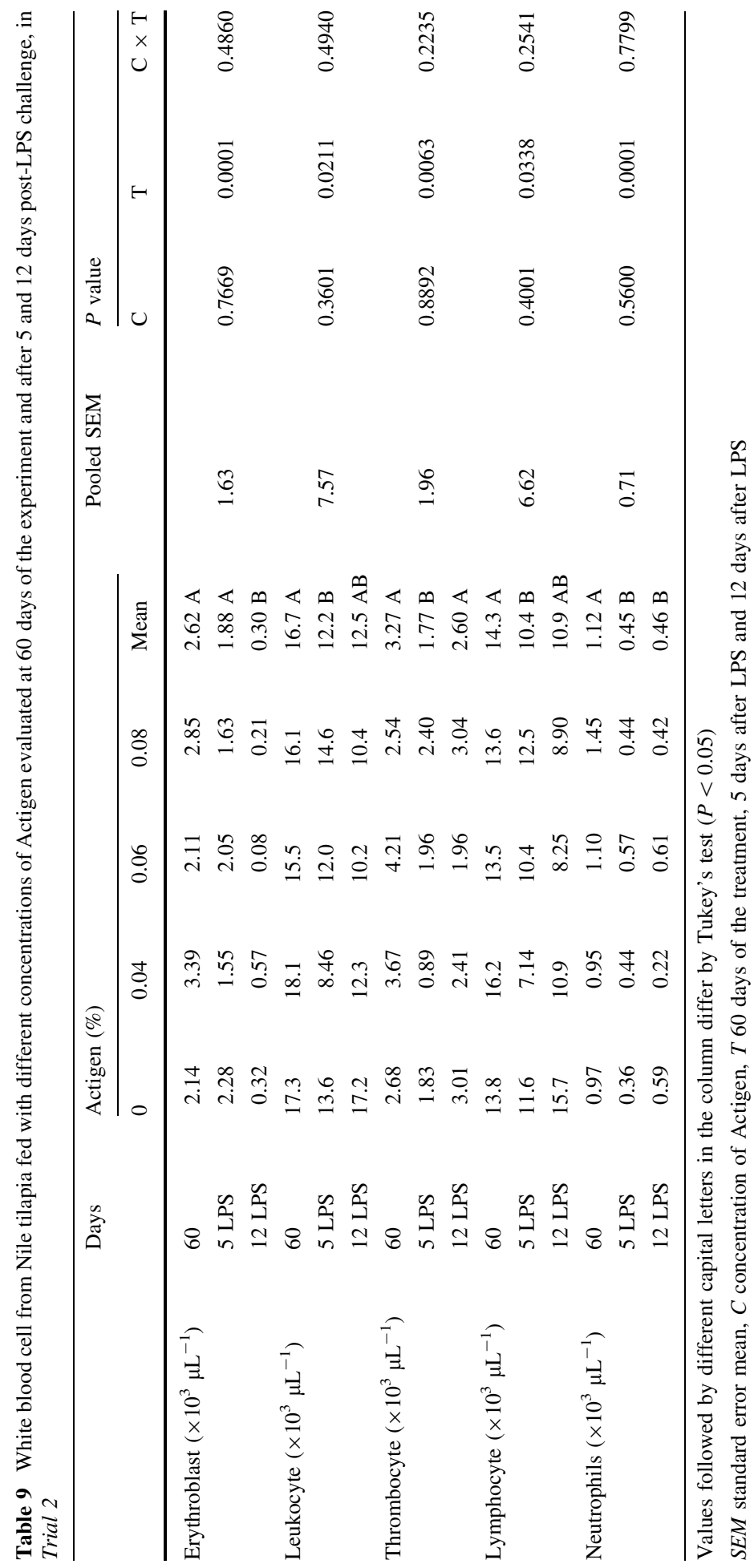


the globulin levels, fish fed a diet with a $0.04 \%$ concentration of ACT showed the highest values $(P<0.05$; Table 10$)$.

\section{Discussion}

In our study, the ACT administration was effective in promoting modulation of the early stages of innate immune response in tilapia (Oreochromis niloticus) primarily after LPS inoculation. The endotoxin was proven effective for the purpose of immune challenge, as it successfully prompted an immune response, such as lysozyme activity and leukocyte respiratory burst. This finding is important for future studies on immune modulators, as well as for bacterial studies specifically, as LPS can be an efficient alternative to bacterial challenges.

In Trial 1, after 60 days of ACT long-term administration, there was an increased response of lysozyme activity and white blood cell counts, even without an antigenic stimulus, because the nonspecific immune system of fish recognizes exogenous substances through Toll-like receptors in blood, tissues and in defense cells membrane that identify proteins and pathogen molecular-associated patterns (PAMP). Immunostimulants often have molecular characteristics similar to composition of PAMP, and after immunostimulants recognition such as ACT, a compound derived from yeast cell walls with active fractions of mannan-rich carbohydrates and proteins, there is an induction of defense components (Magnadóttir 2006; Rebl et al. 2010).

On the contrary, the leukocyte respiratory burst activity was stimulated after 30 days of ACT administration with increased production of reactive oxygen species (EROs) by fish immune cells that will generate potent bactericidal components; the same profile was observed for hemolytic proteins of ACP, being both excellent indicator of animal immunity and pathogen resistance (Giri et al. 2015; Gupta et al. 2014).

The first-generation product derivatives of yeast cell wall, Bio-MOS, have presented the same action in common carp and rainbow trout (Staykov 2004; Staykov et al. 2007), suggesting that ACT, the second-generation product, activates and facilitates antigen processing and stimulates the early stages of immune response, in this way reducing mortality rates and increasing bactericidal activity, lysozyme activity, hemolytic complement activity (alternative pathway) and antibody concentrations (Moran 2004; Staykov 2004).

ACT has also acted directly to improve the intestinal environment, as found in the elevated total height of the villus in the treated group, being an evidence of the improved growth performance, due to a increased surface area and consequently increased nutrient absorption, and health benefits because the intestine is one of the entrances for pathogenic microorganisms. The improved intestinal condition was also found in European sea bass after supplementation with a $0.4 \%$ concentration of MOS in their diet. The results of supplementation were increased growth, immune system activation, and an increased resistance to experimental bacterial infection from inoculation directly into the intestine (Torrecillas et al. 2007). The same benefit was found in carp after the addition of $2.4 \mathrm{~g} \mathrm{~kg}^{-1}$ of MOS to the diet (Staykov et al. 2005; Zhou and Li 2004).

In this study, after 60 days of ACT administration, there was an increase in HTC resulting from the increased release of erythroblasts. The erythroblasts are young erythrocytes and probably were recruited to face an increased energy demand. That greater erythropoietic activity due to immunomodulation is an important mechanism to aid in 


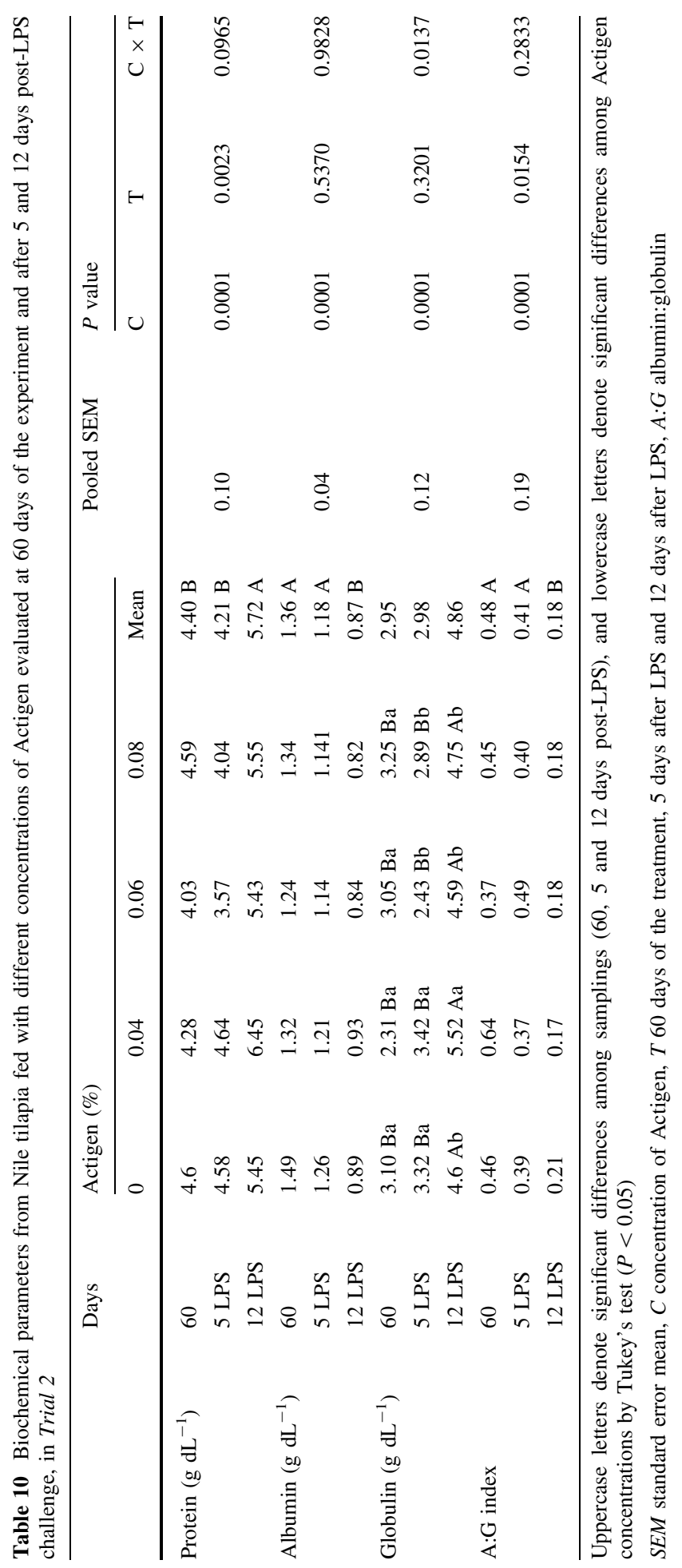


increasing body resistance to stress. The strategic administration of immunostimulants before adverse situations is an alternative to modulate the blood cells that are highly adaptable, to react after handling (Houston and Murrad 1992).

Defense cells also maintain homeostasis, and as observed in our study, after 60 days of ACT stimulation, leukocyte, erythrocyte, thrombocyte, lymphocyte and monocyte counts were higher compared to counts at 30 days. This finding demonstrates that fish fed ACT experience an increased activation of their defense cells. The presence of elevated numbers of leukocytes in the blood may indicate an improved defense response in the body (Sado and Bicudo 2010). The body defense is also made by proteins, and there was an increase in globulins and better A:G index mainly at 60 days of ACT feeding, indicating that a longer administration is required for activating these defense parameters to maintain the immunity of the fish in surveillance (Thomas 2000; Sahoo and Mukherjee 2001).

Therefore, there were no differences in evaluated growth performance among treatments in Trial 1. The same profile was observed in a study in which ACT was added to the diet of birds, and body weight, feed intake, feed conversion, mortality and weight gain were not improved (Melgar and Perdomo 2010). The results of the first trial contributed to the initial understand of this new product, and the long-term administration seems to be more effective in modulate the defense system; however, it was not possible to determine the optimal ACT concentrations required in this specie.

In the second trial, some responses were highlighted by the injection of LPS, because this is an agent that prompts the release of reactive oxygen species and is the causal agent of systemic inflammatory responses that promote a number of unfavorable effects such as liberation of countless endogenous inflammatory mediators (Suchecka et al. 2015).

After LPS injection, the lysozyme activity and the leukocyte burst activity showed more pronounced action at 5 days post-inoculation than at 12 days post-inoculation. This indicates that the effects of LPS are observed earlier in the course of immune reaction. The LPS is known to stimulate the production of proteins such as lysozyme, proteins of the complement system, and cells such as $\mathrm{T}$ and $\mathrm{B}$ lymphocytes and macrophages, resulting directly in increasing innate defense parameters and indirectly in specific defense parameters (Swain et al. 2008; Suchecka et al. 2015).

The increased immune parameters after the bacterial LPS, also known as endotoxin, occurred due to its recognition by the "Toll-like" receptors; nevertheless, in fish these receptors are not fully established. The recognition of the LPS induced expression of cytokines and acute-phase proteins, leading to immunological, pathological, physiological and neuroendocrine effects. These effects become evident when administered after immunostimulants (Swain et al. 2008).

In the current study, the ACT administration and the LPS challenge raised the HGB because of the endotoxin injection, increasing the oxygenation in the tissues (RanzaniPaiva and Silva-Souza 2004). However, this mitigating effect of stress through the improvement of hematological parameters was not observed in other studies, such as Welker et al. (2007), in which channel catfish (Ictalurus punctatus) was fed with Bio-MOS in a mix of yeast byproducts ( $\beta$-glucan, MOS, $S$. cerevisiae) during 4 weeks and challenged with E. ictaluri. The same profile was observed by Sado et al. (2014), in Nile tilapia supplemented with $0,0.2,0.4,0.6,0.8,1,1.5$ and $2.0 \%$ of MOS during 63 days, suggesting that the ACT, which is a second generation of yeast cell wall derivative, is more active and promotes improved results.

In contrast, a general decrease in cells at 5 days post-challenge occurred, with partial recovery demonstrated at 12 days post-challenge. Studies on the inflammatory response in Brazilian fish showed that LPS is the main stimulators of cell migration (Martins et al. 
2004), and suggest that LPS may have triggered chemotaxis of immune cells to the injection focus and thus caused a decrease in leukocytes in the peripheral blood. Lymphocytes and macrophages predominate in the tissue to defend the organism (Iwama and Nakanishi 1996).

In fish, infectious diseases from bacterial and viral etiological agent activate cells of the immune system, changing the percentage of circulating blood cells (Bertolini and Rohovec 1992; Li et al. 2015). In the present study, LPS applied as a challenge factor emulated the presence of pathogens and changed the cell mediated immunity. Once it is known that LPS, even in low doses, affects the blood leukocyte, thrombocyte, monocytes, the macrophages, and the protein of the complement system (Wright et al. 1990).

The evaluation of protein components may be a tool for the assessment of immune status because immune modulators such as ACT and LPS lead to the release of acutephase proteins and pro-inflammatory cytokines (Sen et al. 2014; Suchecka et al. 2015). The increase in total protein, globulins and better A:G index at 12 days after LPS challenge has showed that humoral-mediated immunity is prompted later when compared with cellular response (Thomas 2000; Sahoo and Mukherjee 2001; Zhou et al. 2015).

The survival rate during the experiment was $98 \%$, with no mortalities recorded after the administration of LPS as a challenge factor. In addition, fish did not show clinical signs of endotoxin infection after LPS administration, such as changes in body color or behavioral abnormalities, as are usually found in mammals (Nayak et al. 2008; Wedemeyer et al. 1968). The fish also failed to show a decrease in feed consumption, although LPS can be a powerful anorectic agent for fish, reducing the appetite by influencing the expression of genes related to appetite. The LPS is considered an important virulence factor and is responsible for the lethal effects and clinical manifestations of diseases in humans and animals. However, fish are very resistant to endotoxic shock, making LPS an ideal challenge factor because it modulates defense components but does not cause disease or mortality (Swain et al. 2008; Volkoff and Peter 2004).

There is a shortage of studies with ACT in fish, but Torrecillas et al. (2015) reported that incorporation of a $0.16 \%$ concentration of ACT in the diet of European sea bass for a period of 8 weeks promoted higher specific growth rate and greater body length, in addition to stimulating intestinal cell selection associated with the immune defense and beneficially affecting liver metabolism of lipids. Some studies have also highlighted the positive effects of ACT in the nutrition of pigs at a dose of $0.04 \%$. Corçao et al. (2011a, b) reported that the use of ACT in pigs led to the improvement of growth and health status after challenge with Salmonella and E. coli.

\section{Conclusions}

The use of ACT, an extract derived from yeast cell walls and containing active mannan protein and carbohydrates, showed positive effects on immune parameters, indicating a possible beneficial effect on fish health, mainly after long-term administration. The best dietary supplemental levels were at 0.06 and $0.08 \%$ of ACT mainly after 60 days. However, further studies are required to assess ACT mechanisms and effects on defense and growth performance. 
Acknowledgments The authors would like to thank the Centro de Aquicultura of UNESP (CAUNESP) for supplying the fish for this research and to Alltech ${ }^{\circledR}$ company for donation of the Actigen.

\section{References}

Abimorad EG, Carneiro DJ (2004) Métodos de coleta de fezes e determinação dos coeficientes de digestibilidade da fração proteica e da energia de alimentos para o pacu (Piaractus mesopotamicus). Rev Bras Zootec 33:1101-1109

Barton BA (2000) Salmonid fishes differ in their cortisol and glucose responses to handling and transport stress. North Am J Aquac 62:12-18

Bertolini JM, Rohovec JS (1992) Electrophoretic detection of proteases from different Flexibacter columnaris strains and assessment of their variability. Dis Aquac Org 12:121-128

Biller-Takahashi JD, Takahashi LS, Marzocchi-Machado CM, Zanuzzo FS, Urbinati EC (2012) Hemolytic activity of alternative complement system as an indicator of innate immunity in pacu (Piaractus mesopotamicus). Braz J Anim Sci 41:237-241

Biller-Takahashi JD, Takahashi LS, Saita MV, Gimbo R, Urbinati EC (2013) Leukocytes respiratory burst activity as indicator of innate immunity of pacu Piaractus mesopotamicus. Braz J Biol 73:425-429

Corçao AAP, Hannas MI, Veiga AA (2011a) Use of Actigen ${ }^{\mathrm{TM}}$ - performance, Salmonella control and antimicrobial revitalization. In: "Science and technology in the feed industry" conference, proceedings of Alltech's 27th annual international symposium, Lexington, KY, USA

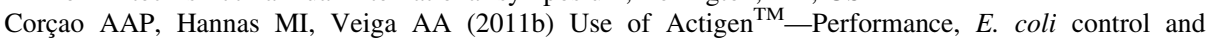
antimicrobial revitalization. In: "Science and technology in the feed industry" conference, proceedings of Alltech's 27th annual international symposium, Lexington, KY, USA

Djordjevic B, Skugor S, Jørgensen SM, Øverland M, Mydland LT, Krasnov A (2009) Modulation of splenic immune responses to bacterial lipopolysaccharide in rainbow trout (Oncorhynchus mykiss) fed lentinan, a beta-glucan from mushroom Lentinula edodes. Fish Shellfish Immunol 26:115-122

Doumas BT, Watson WA, Biggs HG (1971) Albumin standards and the measurement of serum albumin with bromocresol green. Clin Chim Acta 31:87-96

Ellis AE (1990) Serum antiproteases in fish and lysozyme assays. In: Stolen JS, Fletcher TC, Anderson DP, Roberson BS, Van Muiswinkel WB (eds) Techniques in fish immunology. SOS Publications, Fair Haven, pp 95-103

Giri SS, Suda SJ, Sukumaran V, Park SC (2015) Dietary emodin affects the growth performance, immune responses, and disease resistance of Labeo rohita against Aeromonas hydrophila. Aquac Int 23:1-15

Gupta SK, Pal AK, Sahu NP, Saharan N, Mandal SC, Prakash C, Akhtar MS, Prusty AK (2014) Dietary microbial levan ameliorates stress and augments immunity in Cyprinus carpio fry (Linnaeus, 1758) exposed to sublethal toxicity of fipronil. Aquac Res 45:893-906

Haukenes AH, Barton BA (2004) Characterization of the cortisol response following an acute challenge with lipopolysaccharide in yellow perch and the influence of rearing density. J Fish Biol 64:851-862

Hooge DM, Connolly A (2011) Meta-analysis summary of broiler chicken trials with dietary Actigen ${ }^{\circledR}$ (2009-2011). Int J Poult Sci 10:819-824

Houston AH, Murrad A (1992) Erythrodynamics in goldfish, Carassius auratus L.: temperature effects. Physiol Zool 65:55-76

Hung LT (2012) Building new aquafeeds: feeding for health and performance in Tra catfish (Pangasiaodon hypophthalmus). In: Proceedings at Alltech 28th annual symposium, Lexington, KY, May

Iwama G, Nakanishi T (1996) The fish immune system. Academic Press, San Diego

Li M, Chen L, Li E, Yu N, Ding Z, Chen Y, Qin JG (2015) Growth, immune response and resistance to Aeromonas hydrophila of darkbarbel catfish, Pelteobagrus vachelli (Richardson), fed diets with different linolenic acid levels. Aquac Res 46:789-800

Lim C, Webster CD (eds) (2006) Tilapia: biology, culture, and nutrition. Food Products Press, New York Magnadóttir B (2006) Innate immunity of fish (overview). Fish Shellfish Immunol 20:137-151

Mahious AS, Gatesoupe FJ, Hervi M, Metailler R, Ollevier F (2006) Effect of dietary inulin and oligosaccharides as prebiotics for weaning turbot, Psetta maxima (Linnaeus, C. 1758). Aquac Int 14:219-229

Maldarasanu TI, Sara A, Bentea M, Muresan C (2013) The influence of some prebiotics (Actigen, Bio-Mos) administered in laying quails' feeds on growth performances and egg quality. Anim Sci Biotechnol 70:379-380

Martins ML, Pilarski F, Onaka EM, Nomura DT, Fenerick JR, Ribeiro K, Miyazaki DMY, Castro MP, Malheiros EB (2004) Hematologia e resposta inflamatória aguda em Orechromis niloticus 
(Osteichthyes: Cichlidae) submetida aos estímulos único e consecutivo de estresse de captura. Bol Instit Pesca 30:71-80

Martins ML, Miyazaki DMY, Moraes FR de, Ghiraldelli L, Adamante W de B, Mouriño JLP (2008) Ração suplementada com vitaminas $\mathrm{C}$ e E influencia a resposta inflamatória aguda em tilápia do Nilo. Ciênc Rural 38:213-218

Melgar ANV, Perdomo OAF (2010) Efecto de Actigen ${ }^{\circledR}$ en las dietas de pollos de engorde sobre el rendimiento, inmunidad e integridad intestinal. Proyecto especial de graduación del programa de Ingeniería Agronómica. Escuela Agrícola Panamericana, Zamorano. Honduras, 23p

Moran AC (2004) Functional components of the cell wall of Saccharomyces cerevisiae: applications for yeast glucan and mannan. In: Lyons TP, Jacques KA (eds) Proceedings of Alltechs 19th annual symposium, Nottingham University Press, Nottingham, UK

Nayak SK, Swain P, Nanda PK, Dash S, Shukla S, Meher PK, Maiti NK (2008) Effect of endotoxin on the immunity of Indian major carp, Labeo rohita. Fish Shellfish Immunol 24:394-399

Ranzani-Paiva MJT, Silva-Souza EAT (2004) Hematologia de peixes brasileiros. In: Ranzani-Paiva, MJT, Takemoto RS, Lizama MAP (eds) Sanidade de organismos aquáticos. Editora Varela, São Paulo, cap.4:89-120

Rebl A, Goldammer T, Seyfert HM (2010) Toll-like receptor signaling in bony fish. Vet Immunol Immunopathol 134:139-150

Reinhold JG (1953) Manual determination of serum total protein, albumin and globulin fraction by Biuret method. In: Reiner M (ed) Standard method of clinical chemistry. Academic Press, New York, p 88

Ridha MT, Azad IS (2015) Effect of autochthonous and commercial probiotic bacteria on growth, persistence, immunity and disease resistance in juvenile and adult Nile tilapia Oreochromis niloticus. Aquac Res. doi:10.1111/are.12726

Rosenfeld G (1947) Corante pancrômico para hematologia e citologia clínica. Nova combinação dos componentes do May-Grünwald e do Giemsa num só corante de emprego rápido. Mem Instit Butantã 20:329-334

Sado RY, Bicudo AJA (2010) Dietary levamisole influenced hematological parameters of juvenile pacu, Piaractus mesopotamicus (Holmberg 1887). J WAS 41:66-75

Sado RY, Bicudo AJA, Cyrino JEP (2014) Hematology of juvenile pacu, Piaractus mesopotamicus (Holmberg, 887) fed graded levels of mannan oligosaccharides (MOS). Lat Am J Aquat Res 42:30-39

Sahoo PK, Mukherjee SC (2001) Effect of dietary 1,3 $\beta$-glucan on immune responses and disease resistance of healthy and aflatoxin B1-induced immune compromised rohu Labeo rohita Hamilton. Fish Shellfish Immunol 11:683-695

Sara A, Bentea M, Gabor E, Ani A (2012) The effects of Actigen ${ }^{\circledR}$ in broiler chicken nutrition. Anim Sci Biotechnol 69:1-2

Selvaraj V, Samapath K, Sekar V (2006) Adjuvant and immunostimulatory effect of beta glucan administration in combination with lipopolysaccharide enhances survival and some immune parameters in carp challenged with Aeromonas hydrophila. Vet Immunol Immunopathol 114:15-24

Sen SS, Giri SS, Sukumaran V (2014) Immune responses and protection in rohu vaccinated against Aeromonas hydrophila infection. Aquac Int 22:1637-1648

Staykov Y (2004) The influence of Bio-Mos on growth rate and immune status of common carp (Cyprinus carpio). In: Alltech's second annual aquaculture meeting, Dunboyne, Co. Meath., November, oral communication

Staykov Y, Denev S, Spring P (2005) Influence of dietary mannan oligosaccharides (Bio-Mos ${ }^{\circledR}$ ) on growth rate and immune function of common carp (Cyprinus carpio L.). In: Howal B, Flos R (eds) Lessons from the past to optimize the future. European Aquaculture Society, Oostende, pp 431-432 (Special Publication, 35)

Staykov Y, Spring P, Denev S, Sweetman J (2007) Effect of a mannan oligosaccharide on the growth performance and immune status of rainbow trout (Oncorhynchus mykiss). Aquac Int 15:153-161

Suchecka D, Harasym JP, Wilczak J, Gajewska M, Oczkowski M, Gudej S, Błaszczyk K, Kamola D, Filip R, Gromadzka-Ostrowska J (2015) Antioxidative and anti-inflammatory effects of high beta-glucan concentration purified aqueous extract from oat in experimental model of LPS-induced chronic enteritis. J Funct Foods 14:244-254

Swain P, Nayak SK, Nanda PK, Dash S (2008) Biological effects of bacterial lipopolysaccharide (endotoxin) in fish: a review. Fish Shellfish Immunol 25:191-201

Tacon AGJ (1990) The nutrition and feeding of farmed fish and shrimp-a training manual. The essential nutrients. FAO, Brasilia

Thomas JS (2000) Overview of plasma proteins. In: Feldman BF, Zinkl JG, Jain NC (eds) Schalm's veterinary hematology, 5th edn. Lippincott Williams, Wilkins, Philadelphia, pp 891-989 
Toranzo AE, Baya AM, Romalde JL, Hetrick FM (1989) Association of Aeromonas sobria with mortalities of adult gizzard shad, Dorosoma cepedianum Lesueur. J Fish Dis 12:439-448

Torrecillas S, Makol A, Caballero RJ, Montero D, Robaina L, Real F, Sweetman J, Tort L, Izquierdo MS (2007) Immune stimulation and improved infection resistance in European sea bass (Dicentrarchus labrax) fed mannan oligosaccharides. Fish Shellfish Immunol 23:969-981

Torrecillas S, Montero D, Izquierdo M (2014) Improved health and growth of fish fed mannan oligosaccharides: potential mode of action. Fish Shellfish Immunol 36:525-544

Torrecillas S, Montero D, Caballero MJ, Robaina L, Zamorano MJ, Sweetman J, Izquierdo M (2015) Effects of dietary concentrated mannan oligosaccharides supplementation on growth, gut mucosal immune system and liver lipid metabolism of European sea bass (Dicentrarchus labrax) juveniles. Fish Shellfish Immunol 42:508-516

Tort L (2011) Stress and immune modulation in fish. Dev Comp Immunol 35:366-375

Trichet VV (2010) Nutrition and immunity: an update. Aquac Res 41:356-372

Volkoff H, Peter RE (2004) Effects of lipopolysaccharide treatment on feeding of gold fish: role of appetite regulating peptides. Brain Res 998:139-147

Wedemeyer G, Ross AJ, Smith L (1968) Some metabolic effects of bacterial endotoxin in salmonid fishes. J Fish Res Board Can 26:115-122

Welker TL, Lim C, Yildrim-Aksoy M, Shelby R, Klesius PH (2007) Immune response and resistance to stress and Edwardsiella ictaluri challenge in channel catfish, Ictalurus punctatus, fed diets containing commercial whole cell yeast or yeast subcomponents. J WAS 38:24-35

Wintrobe MM (1934) Variations on the size and haemoglobin content of erythrocytes in the blood various vertebrates. Folia Haematol Leipz 51:32-49

Wright S, Ramos R, Tobias P, Ulevitch R, Mathinson A (1990) CD14, a receptor for complexes of lipopolysaccharide (LPS) and LPS binding protein. Science 249:1431-1433

Yassui H, Akino T, Yasuda T, Fukaya M, Wakamura S, Ono H (2007) Gomadalactones A, B and C: novel 3-oxabicyclo [3.3.0] octane compounds in the contact sex pheromone of the white-spotted longicom beetle, Anoplophora malasiaca. Tetra Lett 48:2395-2400

Zhou XQ, Li YL (2004) The effects of Bio-Mos ${ }^{\circledR}$ on intestinal microflora and immune function of juvenile Jian carp (Cyprinus carpio Var. Jian). In: Alltech's annual symposium, nutrition and biotechnology in the feed and food industries, Lexington, pp 24-26

Zhou Q, Xie J, Ge X, Habte-Tsion HM, Bo Liu B, Ren M (2015) Growth performance and immune responses of gibel carp, Carassius auratus gibelio, fed with graded level of rare earth-chitosan chelate. Aquac Int 22:1-11 